\title{
Pengaruh Daya Ledak Otot Lengan, Kelentukan Panggul, dan Koordinasi terhadap Keterampilan Tolak Peluru Gaya O'Brien
}

\author{
Dwi Rizki Ambarwati ${ }^{1}$ *, W. Widiastuti ${ }^{1}$, Karisdha Pradityana ${ }^{1}$ \\ ${ }^{1}$ Pendidikan Olahraga Pascasarjana Universitas Negeri Jakarta. Kampus A Universitas Negeri Jakarta \\ Gedung M Program Pascasarjana. J1. Rawamangun Muka, Jakarta Timur 13220, Indonesia \\ * Corresponding Author. Email: dwirizkiambarwati23@gmail.com \\ Received: 18 July 2017; Revision: 3 October 2017; Accepted: 4 October 2017
}

\begin{abstract}
Abstrak
Penelitian ini bertujuan untuk menemukan jawaban yang akurat secara ilmiah tentang ada atau tidaknya pengaruh daya ledak otot lengan, kelentukan panggul, koordinasi terhadap keterampilan tolak peluru gaya O'Brien. Metode penelitian yang digunakan dalam penelitian ini adalah pendekatan kuantitatif, metode survei dengan teknik tes dan pengukuran. Sedangkan teknik analisis mengunakan pendekatan analisis jalur (path analysis). Hasil Penelitian ini adalah terdapat pengaruh positif antara power otot lengan terhadap keterampilan tolak peluru gaya O'Brien, terdapat pengaruh positif antara kelentukan panggul terhadap keterampilan tolak peluru gaya O'Brien, terdapat pengaruh positif antara koordinasi terhadap keterampilan tolak peluru gaya O'Brien, terdapat pengaruh positif antara power otot lengan terhadap koordinasi terdapat pengaruh positif antara kelentukan panggul terhadap koordinasi, terdapat pengaruh positif antara power otot lengan terhadap kelentukan panggul. Dari hasil penelitian dapat disimpulkan bahwa daya ledak otot lengan, kelentukan panggul serta koordinasi berpengaruh terhadap keterampilan tolak peluru gaya O'Brien.
\end{abstract}

Kata Kunci: tolak peluru, otot, kelentukan, koordinasi

\section{The Effects of Arm Muscle Explosive Power, Hip Flexibility, and Coordination towards the Skill of O'Brien Style Shot Put}

\begin{abstract}
This study aims to find scientifically accurate answers to the presence or absence of the effect of arm muscle explosive power, the flexibility of hip joint, coordination of the O'Brien style shot put skills. The research method used in this research is the quantitative approach, survey method with test and measurement technique. The result of this research is there is positive influence between arm muscle power) to the O'Brien style shot put skills, There is positive influence between the flexibility of hip joint to O'Brien style shot put skills There is a positive influence between the coordination on the O'Brien style shot put skills. There is a positive influence between arm muscle power on coordination. There is a positive influence between the flexibility of hip joint on coordination. There is positive influence between arm muscle power to the flexibility of hip joint. The conclusion is that explosive power of arm muscles, the flexibility of hip joint and coordination influence of the O'Brien style shot put skills.
\end{abstract}

Keywords: shot put skills, arm muscle, agility. coordination

How to Cite: Ambarwati, D., Widiastuti, W., \& Pradityana, K. (2017). Pengaruh daya ledak otot lengan, kelentukan panggul, dan koordinasi terhadap keterampilan tolak peluru gaya O’Brien. Jurnal Keolahragaan, 5(2), 207-215. doi:http://dx.doi.org/10.21831/jk.v5i2.14918

Permalink/DOI: http://dx.doi.org/10.21831/jk.v5i2.14918 


\section{PENDAHULUAN}

Tolak peluru merupakan cabang pembelajaran atletik yang pada umumnya pembelajaran olahraga cabang atletik yang kurang diminati oleh mahasiswa. Hal ini terlihat dari kurangnya antusias mahasiswa dalam mengikuti pembelajaran atletik. Kurangnya antusias mahasiswa disebaban oleh beberapa faktor, salah satu diantaranya adalah penggunaan peluru yang berat dan terbuat dari besi yang menimbulkan rasa waswas dan takut ketika mahasiswa melakukannya. Faktor lainnya adalah penyajian materi yang kurang variatif sehingga menyebabkan mahasiswa malas adalam mengikutinya.

Pembelajaran atletik dikenalkan sebagian atau sekilas pembelajaran hanya berorientasi pada pembelajaran teknik, setelah itu pembelajaran dilanjutkan kegiatan lain, misalnya bermain futsal. Keadaan semacam ini sering terjadi bilamana pembelajaran teknik sudah selesai, sehingga orientasi mahasiswa tidak kepada materi pemebelajaran atletik tetapi pada bermain futsal dan akibatnnya kurang baik bagi cabang atletik.

Ditinjau dari gerakan tolak peluru ada beberapa kondisi fisik dan anggota tubuh yang dapat mempengaruhi pencapaian prestasi tolak peluru. Komponen kondisi fisik yang dapat mempengaruhi prestasi tolak peluru antara lain daya ledak otot lengan. Sedangkan komponen tersebut harus mampu dikerahkan pada teknik tertentu untuk menghasilkan tolakan sejauhjauhnya. Adapun otot-otot yang dominan dalam gerakan melempar otot punggung bagian atas, otot trapesium, otot pektoralis bagian atas, otot deltoisdeus, otot tricep, serta otot pada lengan serta otot pada pergelangan tangan. gerakan menolak keberadaan otot lengan yaitulengan kanan diluruskan untuk menolakkan peluru, disertai dengan lecutan pergelangan tangan dan jari-jari (terutama jari telunjuk, tengah, dan jari manis).

Pendapat tersebut menunjukkan, pada saat menolakkan peluru diperlukan keserasian gerak dari otot-otot bagian atas, otot-otot lengan dan pergelangan tangan. Pada saat menolakkan peluru, otot-otot yang terlibat dikerahkan secara maksimal dan dalam gerakannya dilakukan secara baik dan harmonis serta diakhiri lecutan pergelangan tangan untuk memperoleh tolakan sejauh-jauhnya.

Tujuan pokok tolak peluru adalah menolak peluru dengan jarak sejauh mungkin tentunya dengan menguasi keterampilan teknik dasar sehingga dapat meraih prestasi yang tinggi. Hal ini dapat diperoleh dengan cara melatih faktorfaktor yang menunjang terhadap pencapaian prestasi atlet tersebut. Ada empat aspek latihan yang perlu diperhatikan dan dilatih secara seksama oleh atlet, yaitu (a) latihan fisik, (b) latihan teknik, (c) latihan taktik, dan (d) latihan mental. Seperti faktor fisik, teknik, taktik, dan mental.

Keterampilan tolak peluru, tidak cukup hanya dilatih dari segi tekniknya saja melainkan tiga yaitu fisik, teknik, dan mental yang harus dilatih sehingga memberikan hasil yang maksimal dalam melakukan tolak peluru. Oleh karena dalam diri manusia bukan hanya terbentuk dari fisik melainkan ada jiwanya yang berkaitan dengan mental, maka komponen mental tersebut harus dilatih agar keterampilan tolak peluru bisa dilakukan secara maksimal. Apabila dalam benaknya tersimpan memori gerak dan melalui syaraf motorik dapat memerintahkan alat gerak untuk melakukan tugas sesuai dengan memori yang ada maka mahasiswa tersebut dinyatakan sebagai mahasiswa yang terampil.

Kesalahan gerak terjadi karena tidak lengkapnya memori gerak, ketidaklengkapan memori dapat disebabkan informasi yang masuk tidak dapat diterima secara lengkap, salah persepsi atau pemberi informasi tidak menyampaikan secara rinci dan lengkap. Apabila tidak terjadi karena ketiganya berarti disebabkan oleh kemampuan fisik. Kemampuan fisik yang kurang memadai menyebabkan rangkaian gerak dilakukan dalam keadaan kekurangan daya. Kekurangan daya menjadikan pelempar tidak mampu melakukan rangkain gerakan secara singkat.

Faktor fisik yang menunjang terhadap keterampilan tolak peluru ini. Komponen kondisi fisik yang menunjang terhadap olahraga tolak peluru adalah daya ledak otot lengan, fleksibilitas (kelentukan) dan koordinasi. Daya ledak otot sangat dibutuhkan untuk cabang olahraga yang memerlukan pengerahan otot secara maksimal, cepat, dan akurat. Menurut Badriah (2002, p. 4) Daya ledak otot adalah kemampuan otot atau sekelompok otot melakukan kontraksi secara eksplosife dalam waktu yang singkat. Daya ledak otot dipengaruhi oleh kekuatan kecepatan dan kontraksi otot. Daya ledak yang dimaksud dalam penelitian ini adalah daya ledak otot lengan, daya ledak otot lengan digunakan ketika melakukan tolakan.

Menurut Badriah (2002, p. 25) Kelentukan adalah kemampuan ruang gerak persendian. 
Kutipan tersebut menjelaskan bahwa kelentukan adalah kemampuan tubuh untuk melakukan gerakan persendian dengan sangat luas yang dipengaruhi oleh bentuk persendian, otot, tendon, dan ligamen. Kelentukan dalam penelitan ini dimaksudkan kemampuan sendi-sendi panggul untuk meregang semaksimal mungkin saat melakukan gerakan memutar.

Koordinasi merupakan kemampuan yang dapat mempengaruhi akurasi dalam keterampilan tolak peluru. Koordinasi memberikan kontribusi terhadap penampilan yang nyata pada setiap keterampilan olahraga yang menggunakan tangan dalam melakukan kegiatanya.

Berdasarkan paparan tersebut, untuk menghasilkan jarak tolakan yang jauh diperlukan koordinasi gerak dari seluruh tubuh dan ditunjang oleh kondisi fisik yang prima terutama daya ledak otot dan kelentukan serta didukung juga oleh tingkat koordinasi yang tinggi. Sebagaimana telah disebutkan bahwa tolak peluru sudah merupakan bagian materi yang diajarkan pada tingkat Universitas. Demikian halnya di prodi pendidikan jasmani, kesehatan dan rekreasi STKIP Pangkal Pinang, materi tolak peluru sudah diberikan pada mata kuliah atletik II.

Menurunnya keterampilan tolak peluru yang terjadi pada mahasiswa prodi pendidikan jasmani, kesehatan dan rekreasi STKIP Pangkal Pinang bisa disebabkan oleh berbagai macam faktor diantaranya kurangnya pemahaman mahasiswa mengenai keterkaitan antara komponen kondisi fisik dan psikis dengan teknik dasar tolak peluru sehingga terkadang komponen kondisi fisik dan psikis yang menunjang terhadap keterampilan tolak peluru diabaikan dan berdampak langsung terhadap keterampilan tolak peluru. Sebelum menerapkan metode pengajaran atau metode latihan yang dilakukan oleh pelatihpelatih atau para pengajar untuk pencapaian keterampilan mahasiwa, diharuskan mengetahui dulu komponen fisik dan psikologis apa saja yang dominan untuk cabang olahraga atletik tolak peluru. Sehingga bentuk pengajaran dan latihan mengacu pada komponen kondisi fisik dan psikis yang menunjang berdasarkan hasil penelitian yang ilmiah.

Kebanyakan metode pengajaran dan latihan yang diberikan kepada mahasiswa maupun atlet kurang tepat karena hanya berdasarkan dari dugaan dan pengalaman bukan berdasar pada penelitian yang ilmiah sehingga efeknya jenis pengajaran dan latihannya kurang menunjang pada cabang olahraga atletik tolak peluru, sedangkan dalam cabang olahraga atletik tolak peluru yang dominan adalah daya ledak dan kelentukan serta komponen psikisnya adalah koordinasi karena sesuai karakteristik keterampilan tolak peluru. Dengan adanya penelitian yang penulis lakukan ini, diharapkan menjadi acuan untuk membuat bentuk pengajaran dan latihan yang sesuai dengan karakteristik olahraga tolak peluru. Oleh karena itu, untuk membuktikan keterkaitan komponen kondisi fisik yang mendukung keterampilan tolak peluru penulis mengajukan sebuah penelitian mengenai hubungan kondisi fisik tersebut terhadap keterampilan tolak peluru.

Berdasarkan penjelasan tersebut, maka peneliti mengambil judul "Pengaruh daya ledak otot lengan, kelentukan panggul, dan koordinasi terhadap keterampilan tolak peluru gaya O'Brien Mahasiswa prodi pendidikan jasmani, kesehatan dan rekreasi STKIP Pangkal Pinang.

\section{Keterampilan Tolak Peluru}

Tolak peluru adalah suatu bentuk gerakan menolak atau mendorong suatu alat yang bundar dengan berat tertentu yang terbuat dari logam (peluru) yang dilakukan dari bahu dengan satu tangan untuk mencapai jarak sejauh-jauhnya. Menurut Saputra (2001, p. 73) bahwa tolak peluru merupakan salah satu jenis keterampilan menolakkan benda berupa peluru sejauhjauhnya. Sesuai dengan namanya tolak bukan lempar alat (peluru) ditolak atau didorong dengan satu tangan.

Berdasarkan pengertian tolak peluru dapat disimpulkan, tolak peluru merupakan nomor lempar dalam atletik yang cara pelaksanaannya dengan menolakkan suatu alat yang bundar terbuat dari logam, tembaga atau kuningan yang memiliki berat tertentu yang harus ditolakkan dari bahu untuk mencapai jarak sejauh-jauhnya.

Sidik (2010, p. 106) menjelaskan bahwa ada beberapa teknik dalam tolak peluru linier terbagi dalam fase-fase: Persiapan, luncuran, pengantaran, dan pemulihan. Seperti pada Gambar 1.

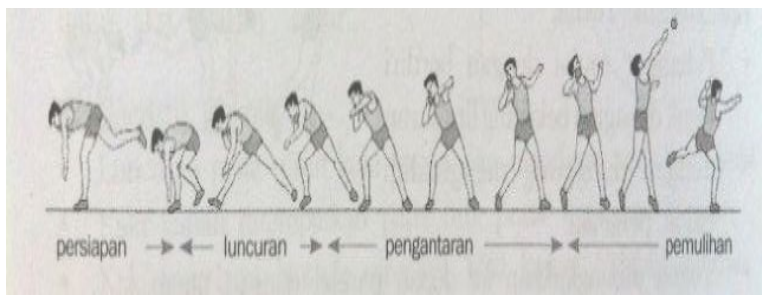

Gambar 1. Tahap Tolakan Peluru Gaya Membelakangi 
Persiapan adalah suatu kegiatan yang akan dipersiapkan sebelum melakukan sebuah kegiatan. Pada tolak peluru khususnya persiapan dilakukan dengan gerakan. Dimulai dari berdiri tegak di bagian belakang lingkaran dengan pung-gung menghadap balok penahan lalu badan di bungkukan ke depan paralel dengan tanah badan seimbang dalam topang tunggal kaki topang dibengkokkan sedangkan kaki bebas ditarik kearah punggung lingkaran. Tahap persiapan dapat dilihat pada Gambar 2.
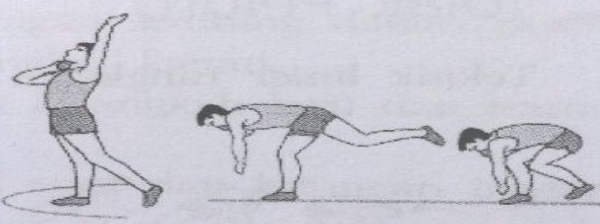

Gambar 2. Fase Persiapan Tolakan Peluru Gaya Membelakangi

Gelincir/luncur adalah gerakan yang di awali dengan pelurusan aktif kaki kiri dalam arah lemparan pada waktu bersamaan dengan suatu dorongan yang kuat dari kaki kanan dengan teknik gerakan badan bergerak dari kaki depan menuju ke tumit. Kaki bebas di dorong rendah ke balok penahan, kaki topang diluruskan di atas tumitnya, kaki topang memelihara kontak dengan tanah selama gerak gelincir itu, dan bahu di jaga tetap bidang terhadap bagian belakang lingkaran. Tahap luncur dapat dilihat pada Gambar 3.

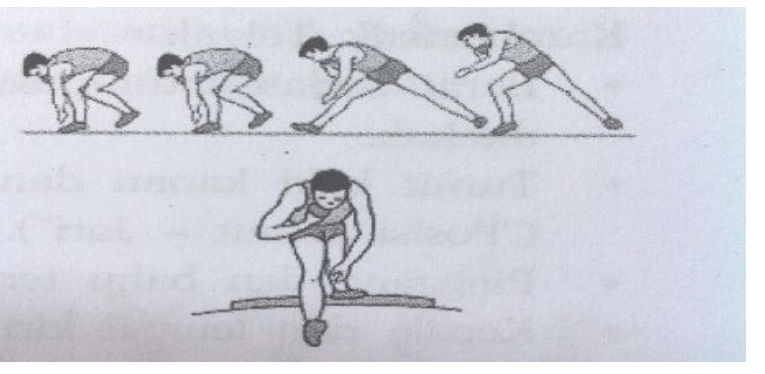

Gambar 3. Fase Gelincir Tolakan Peluru Gaya Membelakangi

Penghantaran/lepasan

merupakan lepasnya peluruh di mulai dengan satu pelurusan yang jelas dari kedua kaki dan suatu pemutaran tubuh di awali dengan kaki kanan dengan teknik gerakan tungkai kanan di luruskan dengan gerakan memutar yang exsplosif sampai pinggang kanan menghadap bagian depan lingkaran lempar, tungkai kiri hampir di luruskan dan di tahan, mengangkat badan, gerakan memilin tubuh diblok oleh lengan kiri dan bahu, siku kanan di putar dan di angkat dalam arah lemparan, dan berat badan di transfer dari kaki kanan ke kaki kiri. Tahap penghantar dapat dilihat pada gambar 4 .

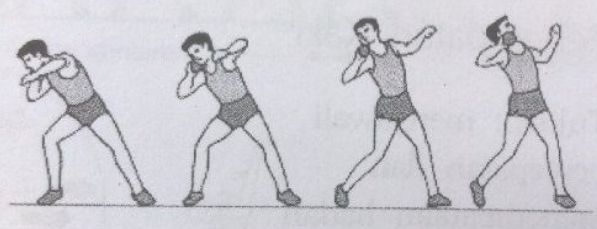

Gambar 4. Fase Pengantaran Tolakan Peluru Gaya Membelakangi

Pemulihan/recovery merupakan gerak akhir setelah pelepasan peluruh dari tangan kanan di teruskan ketungkai kanan dengan cepat di pindahkan ke depan menggantikan kaki kiri dengan teknik kaki-kaki dengan cepat berganti setelah peluruh lepas, kaki kanan di tekuk, badan bagian atas di turunkan, kaki kiri di ayun ke belakang, dan pandangan mata ke bawah.

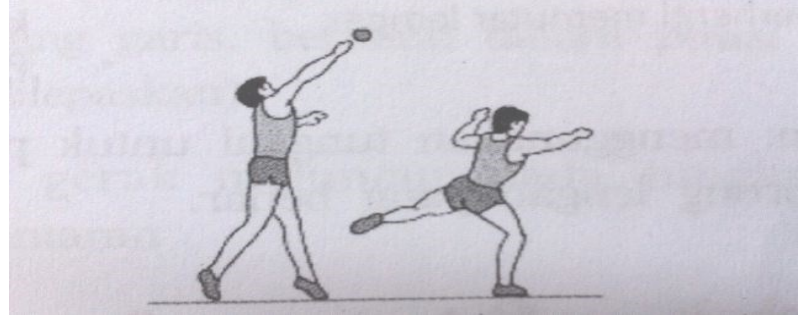

Gambar 5. Fase Pemulihan Tolakan Peluru Gaya Membelakangi

Dalam menolakkan peluru dapat dilakukan dengan bebrapa gaya. Bahagia, Yusuf, \& Suherman (2000, p. 27) menyatakan bahwa gaya tolak peluru yang biasa dilakukan yaitu (1) gaya menyamping, (2) gaya membelakangi dan (3) gaya putaran.

Parry O'Brien merupakan orang yang pertama menemukan gaya linier/gaya membelakangi sektor lapangan, sehingga sampai saat ini dikenal dengan gaya O'Brien. Ada beberapa prasyarat yang harus dimiliki oleh seorang penolak peluru yaitu: (1) kekuatan: kekuatan maksimum power (2) kecepatan: kecepatan berakselerasi (3) kordinasi: kemampuan berirama.

Giriwijoyo, Ikhsan, Harsono, Setiawan, \& Wiramihardja (2005, p. 57) menjelaskan bahwa tujuan tolak peluru ialah untuk mencapai tolakan yang sejauh-jauhnya, sesuai dengan namanya tolak bukan lempar, atau didorong dengan satu tangan bermula diletakan dipangkal bahu, yang berarti menolakan sebuah benda yang terbuat dari logam berukuran tertentu sejauh mungkin. Tolakan adalah suatu gerakan menyalurkan 
tenaga pada suatu benda yang menghasilkan kecepatan pada benda tersebut dan memiliki daya dorong kemuka yang kuat, yang berarti kegiatan mendorong sebuah benda dengan kekuatan tubuh untuk mendapatkan hasil sejauh mungkin dengan mengikuti arah yang benar (Widya, 2004, p. 136).

\section{Daya Ledak Otot Lengan}

Menurut Purnama (2010, p. 57) Daya tahan adalah kemampuan seseorang melakukan kekuatan maksimum dalam waktu sependek pendeknya. Widiastuti (2011, p. 57) mengemukakan bahwa power adalah kemampuan seseorang untuk melakukan kekuatan maksimum, dengan usahanya yang diarahkan dalam waktu sependek-pendeknya, dalam hal ini dapat dkemukakan bahwa, daya ledak otot power $=$ kekuatas atau force $\mathrm{X}$ kecepatan velocity.

Penjelasan diatas tersebut nampak bahwa dua unsur yang penting dalam power yaitu kekuatan otot atau kecepatan otot dalam mengerahkan tenaga maksimal untuk mengatasi tahanan, sehingga dengan demikian dapat disimpulkan batasan power yaitu bahwa power adalah kemampuan otot untuk mengerahkan kekuatan maksimal dalam waktu yang sangat cepat. Seperti yang Mutohir \& Maksum (2007) bahwasanya power adalah gabungan antara kekuatan dan kecepatan otot secara maskimum dan kecepatan maksimum.

\section{Kelentukan Panggul}

Kelentukan merupakan salah satu komponen fisik yang dimiliki setiap orang untuk mewujudkan gerakan yang luwes, lancar dan tidak kaku, maka unsur kondisi fisik ini dikembangkan menjadi kemampuan gerak yang mendukung penguasaan kemampuan keterampilan olahraga.

Kualitas kelentukan yang dimiliki setiap orang berbeda-beda, kelentukan yang baik memungkinkan otot atau sekelompok otot untuk berkontraksi dengan melibatkan sistem lokomotor tubuh untuk berkerja sama dalam melakukan aktifitas gerak. Kelentukan sangat terkait dengan kemampuan ruang gerak sendi seperti pinggul pada saat menekuk, sendi bahu, tulang belakang, pergelangan kaki dan tangan (Nurhassan \& Cholil, 2007, p. 176).

Menurut Sidik (2010) kelentukan sendi dan kelentukan otot sangat tergantung pada elastisitas otot, tendon, dan ligamen Unsur kelentukan sangat terkait dengan masalah ruang gerak sendi dan kebutuhan akan unsur kelentukan sangat terkait dengan cabang olahraga yang ditekuni.

\section{Koordinasi}

Koordinasi adalah perpaduan antara kinerja dan kualitas otot, tulang, dan persendian dalam menghasilkan satu gerak yang efektif dan efisien. Dengan koordinasi yang baik, memungkinkan seseorang mampu melakukan gerakan secara efisien, sehingga mampu melakukan aktifitas gerakan fisik yang baik (Sukadiyanto \& Muluk, 2011, p. 148). Menurut Tangkudung (2006, p. 72) Koordinasi adalah kemampuan untuk melakukan gerakan dengan berbagai tingkat kesukaran dengan cepat dan efisien dan penuh ketepatan. Jadi koordinasi adalah kemampuan otot dalam mengontrol gerak dengan tepat dengan berbagai tingkat kesukaran dengan cepat dan efisien.

Pada dasarnya koordinasi dibedakan menjadi dua macam, yaitu koordinasi umum dan khusus (Bompa \& Haff, 2009, p. 332). Koordinasi umum merupaka kemampuan seluruh tubuh dalam menyesuaikan dan mengatur gerakan secara simultan pada saat yang bersamaan. Sedangkan koordinasi khusus merupakan koordinasi antar beberapa anggota badan, yaitu kemampuan untuk mengkoordinasikan gerak dari sejulah anggota badan secara bersamasama.

\section{METODE}

Metode penelitian yang digunakan dalam penelitian ini adalah pendekatan kuantitatif, metode survei dengan teknik tes dan pengukuran. Sedangkan teknik analisis mengunakan pendekatan analisis jalur (path analysis) yaitu penelitian yang akan mengkaji atau yang akan menganalisis keterkaitan antar variabel penelitian dengan mengukur pengaruh langsung antara variabel endogen (variabel terikat) adalah $\mathrm{Y}$ dengan variabel eksogen (bebas) adalah X1, X2, dan X3. Penelitian ini dilaksanakan di STKIP Pangkal Pinang, Populasi dalam penelitian ini adalah mahasiswa prodi pendidikan jasmani, kesehatan dan rekreasi STKIP Pangkal Pinang. sampel penelitian berjumlah 50 orang. Sedangkan uji coba instrumen berjumlah 30 orang dengan menggunakan orang yang berbeda. Teknik pengambilan sampel dilakukan dengan menggunakan teknik Purposive Sampling, yaitu penentuan sampel dengan pertimbangan tertentu. Berdasarkan hal tertentu maka sampel dalam penelitian ini ditetapkan mahasiswa prodi pendidikan jasmani, kesehatan dan rekreasi STKIP 
Pangkal Pinang. Teknik pengumpulan data menggunakan instrumen penelitian. Instrumen penelitian sebelum digunakan untuk mengumpulkan data yang harus terlebih dahulu di uji cobakan, guna mendapatkan validitas dan reliabilitasnya.

\section{HASIL DAN PEMBAHASAN}

\section{Hasil}

Pengaruh Eksplosif Daya Ledak Otot Lengan, Kelentukan Panggul dan Koordinasi terhadap Keterampilan Tolak Peluru Gaya O’Brien

Kaidah pengujian signifikansi mempergunakan program SPSS versi 16.0 yang ditunjukan oleh Tabel 1. Berdasarkan hasil analisis pada Tabel 1, diperoleh bahwa model 1 , Fo $=$ 2.386; $\mathrm{db} 1=1 \mathrm{db} 2=48, p$-value $=0,00<0,05$ atau $\mathrm{H}_{\mathrm{O}}$ ditolak. Dengan demikian, variable Power otot lengan secara simultan berpengaruh terhadap kelentuk-an panggul sendi panggul. Adapun pengaruh langsung positif dapat dilihat dari ouput pada Tabel 2.

Dari Tabel 2 coefficients, diperoleh data dengan berturut-turut: $\rho x_{1} x_{2}=0,990 ; \mathrm{t}_{0}=1,033$, p-value $=0,00<0,05, \mathrm{H}_{0}$ ditolak, yang berarti Daya Ledak Otot Lengan berpengaruh langsung positif terhadap kelentukan panggul.

Pengaruh Daya Ledak Otot Lengan dan Kelentukan Panggul terhadap Keterampilan Tolak Peluru Gaya O’Brien

Kaidah pengujian signifikansi mempergunakan program SPSS versi 16.0 yang ditunjukan oleh data pada Tabel 3. Berdasarkan hasil analisis pada Tabel 3, diperoleh bahwa model 1, Fo $=712,38 ; \mathrm{db} 1=2 \mathrm{db} 2=77$, p-value $=0,00<$ 0,05 atau $\mathrm{H}_{\mathrm{O}}$ ditolak. Dengan demikian, variable Daya Ledak Otot Lengan dan Kelentukan Panggul secara simultan berpengaruh terhadap Koordinasi. Adapun pengaruh langsung positif dapat dilihat pada Tabel 4.

Dari Tabel 4 coefficients, diperoleh data dengan berturut-turut: (1) $\rho x_{1} x_{3}=0,452 ; \mathrm{t}_{0}=$ 2,434 , p-value $=0,019<0,05, \mathrm{H}_{0}$ ditolak, yang berarti Daya Ledak Otot Lengan berpengaruh langsung positif terhadap Koordinasi. (2) $P x_{2} x_{3}=0,353 ; \mathrm{t}_{0}=2,881, \mathrm{p}$-value $=0,006<0,05$, $\mathrm{H}_{0}$ ditolak, yang berarti Kelentukan Panggul berpengaruh langsung positif terhadap Koordinasi.
Pengaruh Daya Ledak Otot Lengan dan Kelentukan Panggul Berpengaruh secara Simultan terhadap Koordinasi

Kaidah pengujian signifikansi mempergunakan program SPSS versi 16 yang ditunjukan oleh data pada Tabel 5. Berdasarkan hasil analisis pada Tabel 5, diperoleh bahwa model 1, Fo $=7,082 ; \mathrm{db} 1=3 \mathrm{db} 2=46$, p-value $=0,001<$ 0,05 atau $\mathrm{H}_{\mathrm{O}}$ ditolak. Dengan demikian, variable Power otot lengan, Kelentukan Panggul dan Koordinasi secara simultan berpengaruh terhadap keterampilan tolak peluru gaya O'Brien. Adapun pengaruh langsung positif dapat dilihat dari output pada Tabel 6 .

Dengan menggunakan metode backward, diperoleh koefisien jalur yang ditunjukkan oleh kolom standardized coefficients (Beta). Dari Tabel 6 coefficients, diperoleh data dengan berturut-turut: (1) $\rho y x_{I}=0,332 ; \mathrm{t}_{0}=1,365$, $\mathrm{p}$ value $=0,021<0,05, \mathrm{H}_{0}$ ditolak, yang berarti Ekslosif Power otot tungkai berpengaruh langsung positif terhadap Keterampilan Tolak Peluru Gaya O'Brien. (2) $\rho y x_{2}=0,171 ; \mathrm{t}_{0}=1.271, \mathrm{p}$ value $=0,000<0,05, \mathrm{H}_{0}$ ditolak, yang berarti ke Kelentukan Panggul berpengaruh langsung positif terhadap Keterampilan Tolak Peluru Gaya O'Brien (3) $\rho y x_{3}=0,163 ; \mathrm{t}_{0}=1,701, \mathrm{p}$-value $=$ $0,015<0,05, \mathrm{H}_{0}$ ditolak, yang berarti Koordinasi berpengaruh langsung positif terhadap prestasi Keterampilan Tolak Peluru Gaya O’Brien.

\section{Pembahasan}

Berdasarkan hasil pengujian hipotesis secara individual ternyata power otot tungkai, Kelentukan Panggul dan koordinasi berpengaruh signifkan terhadap Keterampilan tolak peluru gaya O'Brien pada mahasiswa prodi pendidikan jasmani, kesehatan dan rekreasi STKIP Pangkal Pinang. Persamaan struktural dari hasil analisis jalur dari power otot tungkai, Kelentukan Panggul dan Koordinasi terhadap Keterampilan tolak peluru gaya O'Brien adalah sebagai berikut: $\quad Y=0,332 \rho_{1 \mathrm{y}}+0,171 \rho_{2 y}+$ $0,163 \rho_{3 y}+0,827 \varepsilon_{3}$.

Pengaruh power otot lengan $\left(\mathrm{X}_{1}\right)$ secara langsung mempengaruhi Keterampilan tolak peluru gaya $\mathrm{O}^{\prime}$ Brien $(\mathrm{Y})$ sebesar $0,332^{2} \times 100 \%=$ $11,02 \%$. Pengaruh kelentukan panggul $\left(\mathrm{X}_{2}\right)$ secara langsung mempengaruhi Keterampilan tolak peluru gaya O'Brien (Y) sebesar $0,171^{2} \mathrm{x}$ $100 \%=2,92 \%$. Sementara pengaruh motivasi berprestasi $\left(\mathrm{X}_{3}\right)$ secara langsung mempengaruhi Keterampilan tolak peluru gaya O'Brien (Y) sebesar $0,163^{2} \times 100 \%=2,66 \%$. 
Dari uraian tersebut dapat dilihat seberapa besar pegaruh variabel power otot tungkai, Kelentukan Panggul dan Koordinasi terhadap Keterampilan Tolak Peluru Gaya O'Brien, maka dapat ditarik kesimpulannya bahwa variabel $X_{1}$, $X_{2}$, dan $X_{3}$ berpengaruh langsung terhadap variabel $\mathrm{Y}$.

Kedua, hipotesis terdapat pengaruh yang signifikan variabel eksplosive power otot tungkai dan kelentukan panggul terhadap Koordinasi setelah dilakukan pengujian hipotesis terbukti secara individu signifikan berpengaruh terhadap Keterampilan tolak peluru gaya O'Brien pada mahasiswa prodi pendidikan jasmani, kesehatan dan rekreasi STKIP Pangkal Pinang. Persamaan struktural dari hasil analisis jalur dari power otot tungkai terhadap Koordinasi dan Kelentukan Panggul terhadap Koordinasi adalah $\mathrm{X}_{3}=0,452$ $\rho_{31}+0,353 \rho_{32}+0,178 \varepsilon_{2}$.

Tabel 1. Model-1 ANOVA ${ }^{\mathrm{b}}$

\begin{tabular}{llrrrrr}
\hline \multicolumn{1}{c}{ Model } & Sum of Squares & Df & Mean Square & \multicolumn{1}{c}{ F } & Sig. \\
\hline 1 & Regression & 4803.186 & 1 & 4803.186 & 2.386 & $.000^{\mathrm{a}}$ \\
Residual & 96.671 & 48 & 2.014 & & \\
Total & 4899.857 & 49 & & & \\
\hline
\end{tabular}

Tabel 2. Model-1 Coefficients ${ }^{\mathrm{a}}$

\begin{tabular}{|c|c|c|c|c|c|c|}
\hline & \multirow{2}{*}{ Model } & \multicolumn{2}{|c|}{ Unstandardized Coefficients } & \multirow{2}{*}{$\begin{array}{c}\text { Standardized Coefficients } \\
\text { Beta }\end{array}$} & \multirow[b]{2}{*}{$\mathbf{t}$} & \multirow{2}{*}{ Sig. } \\
\hline & & B & Std. Error & & & \\
\hline \multirow[t]{2}{*}{1} & (Constant) & .503 & 1.033 & & .487 & .629 \\
\hline & $\mathrm{X} 2$ & .990 & .020 & .990 & 48.836 & .000 \\
\hline
\end{tabular}

Tabel 3. Model-2 ANOVA ${ }^{\text {b }}$

\begin{tabular}{llrrrrr}
\hline \multicolumn{1}{c}{ Model } & Sum of Squares & Df & Mean Square & F & Sig. \\
\hline 1 & Regression & 4743.111 & 2 & 2371.55 & 712.38 & $.000^{\mathrm{a}}$ \\
Residual & 156.465 & 47 & 3.329 & & \\
Total & 4899.576 & 49 & & & \\
\hline
\end{tabular}

Tabel 4. Model-2 Coefficients ${ }^{\mathrm{a}}$

\begin{tabular}{|c|c|c|c|c|c|c|}
\hline & \multirow{2}{*}{ Model } & \multicolumn{2}{|c|}{ Unstandardized Coefficients } & \multirow{2}{*}{$\begin{array}{c}\text { StandardizeCoefficients } \\
\text { Beta }\end{array}$} & \multirow{2}{*}{$\mathbf{t}$} & \multirow{2}{*}{ Sig. } \\
\hline & & B & Std. Error & & & \\
\hline \multirow[t]{3}{*}{1} & (Constant) & .688 & 1.332 & & .516 & .608 \\
\hline & $\mathrm{X} 2$ & .452 & .186 & .452 & 2.434 & .019 \\
\hline & $\mathrm{X} 1$ & .535 & .186 & .535 & 2.881 & .006 \\
\hline
\end{tabular}

Tabel 5. Model-3 ANOVA ${ }^{\text {b }}$

\begin{tabular}{llrrrrr}
\hline \multicolumn{1}{c}{ Model } & Sum of Squares & df & Mean Square & F & Sig. \\
\hline 1 & Regression & 1548.107 & 3 & 516.036 & 7.082 & $.001^{\mathrm{a}}$ \\
Residual & 3351.706 & 46 & 72.863 & & \\
Total & 4899.812 & 49 & & & \\
\hline
\end{tabular}

Tabel 6. Model-3 Coefficients ${ }^{\mathrm{a}}$

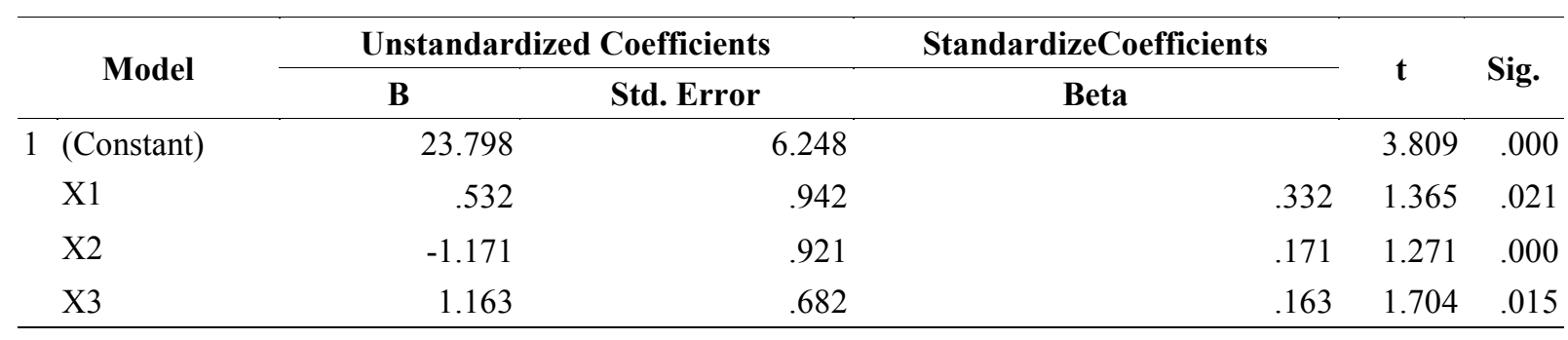


Pengaruh langsung variabel $\mathrm{X}_{1}$ terhadap $\mathrm{X}_{3}\left(\mathrm{X}_{1} \rightarrow \mathrm{X}_{3}\right)$ atau $\left(\mathrm{r}_{12}\right)=0,452$. Jadi pengaruh power otot tungkai $\left(\mathrm{X}_{1}\right)$ secara langsung mempengaruhi motivasi berprestasi $\left(\mathrm{X}_{3}\right)$ sebesar 0 , $452^{2} \times 100 \%=20,43 \%$. Dari urian tersebut dapat dilihat pengaruh variabel power otot tungkai dan kelentukan panggul secara langsung terhadap Koordinasi sisanya merupakan pengaruh dari variabel-variabel lain selain dari variabel power otot tungkai dan kelentukan panggul. Variabel lain yang dapat mempengaruhi Koordinasi antara lain faktor internal meliputi pembawaan atlet, pengalaman masa lalu, cita-cita dan harapan.

Ketiga, hipotesis terdapat pengaruh signifikan power otot tungkai terhadap kelentukan panggul. setelah dilakukan pengujian hipotesis terbukti secara individu signifikan berpengaruh terhadap Kelentukan mahasiswa prodi pendidikan jasmani, kesehatan dan rekreasi STKIP Pangkal Pinang. Persamaan struktural dari hasil analisis jalur dari power otot tungkai terhadap kelentukan panggul adalah $\mathrm{X}_{2}=0,990 \rho_{21}+$ $0,980 \varepsilon_{1}$.

Pengaruh langsung variabel $\mathrm{X}_{1}$ terhadap $\mathrm{X}_{2}\left(\mathrm{X}_{1} \rightarrow \mathrm{X}_{2}\right)$ atau $\left(\mathrm{r}_{13}\right)=0,990$. Jadi pengaruh power otot tungkai $\left(\mathrm{X}_{1}\right)$ secara langsung mempengaruhi kelentukan $\left(\mathrm{X}_{2}\right)$ sebesar $0,990^{2} \times 100 \%=$ $98 \%$. Dari urian tersebut dapat dilihat pengaruh variabel power otot tungkai secara langsung terhadap Kelentukan Panggul sisanya merupakan pengaruh dari variabel-variabel lain selain dari variabel power otot tungkai. Variabel lain yang dapat mempengaruhi kelentukan adalah faktor latihan dan biomotorik lainnya.

Dari hasil uraian diatas dapat kita lihat hasil penelitian tentang pengaruh power otot tungkai, Kelentukan Panggul dan Koordinasi berprestasi terhadap Keterampilan tolak peluru gaya O'Brien pada mahasiswa prodi pendidikan jasmani, kesehatan dan rekreasi STKIP Pangkal Pinang. Temuan ini menunjukkan, bahwa untuk meningkatkan prestasi atlet, seorang atlet harus memiliki power otot tungkai, Kelentukan Panggul dan Koordinasi yang baik tentunya, dimana ketiganya memiliki pengaruh dalam meningkatkan prestasi mahasiswa prodi pendidikan jasmani, kesehatan dan rekreasi STKIP Pangkal Pinang.

\section{SIMPULAN}

Terdapat pengaruh positif antara power otot lengan $\left(\mathrm{X}_{1}\right)$ terhadap Keterampilan tolak peluru gaya O'Brien (Y) pada mahasiswa Prodi Pendidikan Jasmani, Kesehatan dan Rekreasi
STKIP Pangkal Pinang. (2) Terdapat pengaruh positif antara kelentukan panggul $\left(\mathrm{X}_{2}\right)$ terhadap keterampilan tolak peluru gaya O'Brien (Y) pada mahasiswa Prodi Pendidikan Jasmani, Kesehatan dan Rekreasi STKIP Pangkal Pinang. (3) Terdapat pengaruh positif antara koordinasi $\left(\mathrm{X}_{3}\right)$ terhadap keterampilan tolak peluru gaya O'Brien (Y) pada mahasiswa Prodi Pendidikan Jasmani, Kesehatan dan Rekreasi STKIP Pangkal Pinang. (4) Terdapat pengaruh positif antara power otot lengan $\left(\mathrm{X}_{1}\right)$ terhadap koordinasi $\left(\mathrm{X}_{3}\right)$ pada Prodi Pendidikan Jasmani, Kesehatan dan Rekreasi STKIP Pangkal Pinang. (5) Terdapat pengaruh positif antara kelentukan panggul $\left(\mathrm{X}_{2}\right)$ terhadap koordinasi $\left(\mathrm{X}_{3}\right)$ pada mahasiswa Prodi Pendidikan Jasmani, Kesehatan dan Rekreasi STKIP Pangkal Pinang. (6) Terdapat pengaruh positif antara power otot lengan $\left(\mathrm{X}_{1}\right)$ terhadap kelentukan panggul $\left(\mathrm{X}_{2}\right)$ pada mahasiswa Prodi Pendidikan Jasmani, Kesehatan dan Rekreasi STKIP Pangkal Pinang. Dengan demikian keterampilan tolak peluru gaya O'Brien dapat ditingkatkan melalui peningkatan power otot lengan, kelentukan panggul dan koordinasi.

Dalam proses belajar gerak banyak faktor yang berpengaruh, seperti faktor atlet, faktor latihan, faktor lingkungan dan faktor pelatih. Faktor atlet merupakan faktor penentu utama dalam proses belajar gerak. Karena pada dasarnya setiap individu memiliki kualitas diri dan sifat yang berbeda satu sama lain. Kenyataan ini membawa konsekuensi bahwa setiap individu memiliki potensi yang berbeda-beda untuk berhasil dalam mempelajari keterampilan gerak tertentu.

Dalam hal ini, kondisi yang ada pada diri atlet merupakan faktor penting yang perlu dipahami oleh pelatih. Sehingga strategi melatih dan pembuatan program latihan, dapat pelatih sesuaikan dengan kondisi atlet sebagai penerapan cara-cara untuk tercapainya tujuan belajar gerak. Kemampuan kondisi fisik merupakan sarana utama untuk melakukan gerakan dan untuk memberikan dukungan dalam pelaksanaan gerakan keterampilan, besarnya peran setiap unsur kemampuan tersebut tidak selalu sama untuk setiap macam gerakan dan keterampilan cabang olahraga.

\section{DAFTAR PUSTAKA}

Badriah, D. L. (2002). Fisiologi olahraga dalam perspektif teoretis dan praktik. Bandung: Pustaka Ramadhan. 
Bahagia, Y., Yusuf, U., \& Suherman, A. (2000). Atletik. Jakarta: Departemen Pendidikan Nasional, Direktorat Jenderal Pendidikan Dasar dan Menengah.

Bompa, T. O., \& Haff, G. (2009). Periodization : theory and methodology of training. Iowa: Human Kinetics.

Giriwijoyo, S., Ikhsan, M., Harsono, Setiawan, I., \& Wiramihardja, K. K. (2005). Manusia dan olahraga. Bandung: Institut Teknologi Bandung.

Mutohir, T. C., \& Maksum, A. (2007). Sport development index, alternatif baru mengukur kemajuan pembangunan bidang keolahragaan. Jakarta: PT Indeks.

Nurhassan, H., \& Cholil, D. H. (2007). Modul tes dan pengukuran keolahragaan. Bandung: FPOK, Universitas Pendidikan Indonesia.
Purnama, S. K. (2010). Kepelatihan bulutangkis modern. Surakarta: Yuma Pustaka.

Saputra, Y. M. (2001). Dasar-dasar keterampilan atletik. Jakarta: Departemen Pendidikan Nasional.

Sidik, D. Z. (2010). Mengajar dan melatih atletik. Bandung: PT Remaja Rosdakarya.

Sukadiyanto \& Muluk, D. (2011). Pengantar teori dan metodologi melatih fisik. Bandung: Lubuk Agung.

Tangkudung, J. (2006). Kepelatihan olahraga, pembinaan prestasi olahraga. Jakarta: Cerdas Jaya.

Widiastuti, W. (2011). Tes dan pengukuran olahraga. Jakarta: PT Bumi Timur Jaya.

Widya, M. D. A. (2004). Belajar berlatih gerakgerak dasar atletik dalam bermain. Jakarta : Raja Grafindo Persada. 